\title{
Kualitas dan Kadar Amonia Litter Akibat Penambahan Sinbiotik dalam Ransum Ayam Broiler
}

\section{Quality and Levels of Ammonia Litter Effects of Addition Synbiotic in Broiler Diets}

\author{
E. A. F. Marang, L. D. Mahfudz*, T. A. Sarjana, dan S. Setyaningrum \\ Fakultas Peternakan dan Pertanian, Universitas Diponegoro, \\ Kampus Tembalang, Semarang 50275 - Indonesia \\ *E-mail: inditik@yahoo.com \\ (Diterima: 7 Juli 2019; Disetujui: 13 September 2019)
}

\begin{abstract}
ABSTRAK
Penelitian bertujuan untuk mengkaji perubahan kualitas dan kadar amonia litter pada pemeliharaan ayam broiler akibat penambahan sinbiotik dari inulin ekstrak umbi gembili dan bakteri Lactobacillus plantarum. Materi yang digunakan adalah ayam broiler day old chick (DOC) unsexed sebanyak 144 ekor dengan bobot awal 45,68 \pm 1,52 g dialokasikan ke dalam rancangan acak lengkap (RAL) dengan 4 perlakuan 6 ulangan. Perlakuan yang diberikan berupa penambahan sinbiotik yaitu sebagai berikut T0 : ransum basal (tanpa penambahan sinbiotik); T1 : sinbiotik $1 \mathrm{ml} / 100 \mathrm{~g}$ ransum; T2 : sinbiotik $2 \mathrm{ml} / 100 \mathrm{~g}$ ransum dan $\mathrm{T} 3$ : sinbiotik $3 \mathrm{ml} / 100 \mathrm{~g}$ ransum. Parameter yang diamati adalah kadar air, $\mathrm{pH}$, suhu, dan amonia litter. Data yang diperoleh dianalisis dan data yang menunjukkan pengaruh perlakuan yang nyata di uji lanjut dengan uji wilayah Duncan. Hasil penelitian menunjukkan bahwa penambahan sinbiotik signifikan $(\mathrm{P} \leq 0,05)$ menurunkan kadar amonia dan $\mathrm{pH}$ litter, dan signifikan $(\mathrm{P} \leq 0,05)$ meningkatkan kadar air litter, sedangkan terhadap suhu litter tidak berpengaruh signifikan ( $\mathrm{P}>0,05)$. Kesimpulan dari penelitian ini adalah penambahan sinbiotik sebanyak $2 \mathrm{ml} / 100 \mathrm{~g}$ ransum dapat memperbaiki kualitas dan kadar amonia litter.
\end{abstract}

Kata kunci: broiler, kadar amonia, kualitas litter, sinbiotik

\section{ABSTRACT}

The aim of this research is to examine change the quality and levels of ammonia litter on the maintenance of broiler effects of addition synbiotic derived from inulin of gembili tubers extract and Lactobacillus plantarum bacteria. The material used was broiler day old chick (DOC) unsexed as many as 144 chickens with initial body weight 45,68 $\pm 1,52 \mathrm{~g}$ allocated into a completely randomized design with 4 treatment 6 replications. Treatments applied of addition synbiotic was T0: basal ration (without the addition of synbiotic); T1: synbiotic $1 \mathrm{ml} / 100 \mathrm{~g}$ of ration T2: synbiotic $2 \mathrm{ml} / 100 \mathrm{~g}$ of ration and T3: synbiotic $3 \mathrm{ml} / 100 \mathrm{~g}$ of ration. Parameters observed were temperature, $\mathrm{pH}$, water content and ammonia of litter. The data were statistically analyzed and the data were showed significant continued by Duncan test. The result showed an addition of synbiotic was significantly $(P \leq 0,05)$ decreases ammonia levels and $p H$ of litter, but significantly $(P \leq 0,05)$ increases litter water content, while litter temperature was not significantly affected $(P>0,05)$. The conclusion of this research is the addition of synbiotic at $2 \mathrm{ml} / 100 \mathrm{~g}$ of the ration can improve quality and ammonia levels of litter.

Keywords: ammonia levels, broiler, litter quality, synbiotic

\section{PENDAHULUAN}

Ayam broiler merupakan ternak yang memiliki laju pertumbuhan yang cepat dan masa panen singkat. Selain itu, ayam broiler memiliki daya tahan tubuh rendah dan ekskretanya memiliki emisi gas amonia yang tinggi. Hal ini dikarenakan pakan ayam broiler mengandung kadar protein yang tinggi. Jumlah nitrogen yang tidak 
terserap oleh tubuh akan dibuang bersama zat-zat yang tidak terserap lainnya berupa ekskreta sehingga menyebabkan munculnya amonia. Amonia yang tinggi merupakan salah satu penyebab timbulnya berbagai penyakit pada ayam. Amonia adalah limbah dari dekomposisi nitrogen oleh mikroba dalam ekskreta yang berupa asam urat, asam amino, peptida dan protein yang tidak diserap (Widodo et al., 2009). Amonia terbentuk di dalam kandang ayam berasal dari tingginya protein pakan $(21-23 \%)$ yang tidak tercerna sehingga dikeluarkan bersama ekskreta yang terdiri dari feses dan urin. Oleh karena itu, protein pakan yang tidak tercerna di dalam saluran pencernaan ayam dapat dikurangi dengan penambahan sinbiotik dalam pakan.

Sinbiotik adalah gabungan antara prebiotik dan probiotik. Kombinasi prebiotik inulin ekstrak umbi gembili (IEUG) dengan probiotik Lactobacillus plantarum diharapkan bersinergi menjadi sinbiotik karena bakteri tersebut memanfaatkan serat inulin. Sebagai prebiotik, inulin dari umbi gembili merupakan prebiotik yang digolongkan sebagai serat yang mudah larut dalam saluran pencernaan dan dapat meningkatkan asam lemak rantai pendek (short chain fatty acid) yang merupakan pakan dari probiotik. Sebagai probiotik, Lactobacillus plantarum adalah kultur mikrobia golongan bakteri asam laktat (BAL) yang mampu menekan perkembangan mikroba patogen, menurunkan $\mathrm{pH}$, sehingga mengaktifkan enzim pencernaan. Kerja BAL ini akan mencegah terjadinya infeksi dan meningkatkan kecernaan pakan dalam saluran pencernaan. Hasil perkembangan BAL akan meningkatkan asam lemak rantai pendek dan asam laktat, menurunkan $\mathrm{pH}$ dan mengaktifkan enzim pencernaan, sehingga saluran pencernaan menjadi lebih sehat dan meningkatkan kecernaan protein (Kim et al., 2015).

Penurunan produksi amonia dapat ditempuh melalui beberapa hal antara lain peningkatan efisiensi pakan sehingga berdampak padakeluaran nitrogen yang sedikit dan perbaikan kondisi litter seperti suhu, kelembaban dan $\mathrm{pH}$ litter. Probiotik dapat menekan aktivitas enzim urease dalam usus kecil, sehingga kadar gas organik (amonia) dalam ekskreta menurun. Probiotik berperan untuk menekan aktivitas mikroorganisme pengurai nitrogen pada ekskreta dan litter sehingga kadar amonia dalam kandang rendah (Sjofjan, 2003). Penurunan kandungan gas organik ekskreta tersebut karena probiotik dapat meningkatkan kecernaan protein pakan dan dapat menurunkan jumlah asam urat. Asam urat tersebut dimanfaatkan menjadi protein organik sehingga asam urat ekskreta menurun, jika $\mathrm{N}$ ekskreta menurun maka amonia menurun (Chiang dan Hsieh, 1995). Sinbiotik diharapkan mampu mengoptimalkan kecernaan protein sehingga dapat meningkatkan retensi nitrogen dan keluaran $\mathrm{N}$ berkurang.

Derajat keasaman atau $\mathrm{pH}$ litter dibawah 7 dapat menurunkan volatilisasi amonia sebaliknya $\mathrm{pH}$ litter diatas 8 dapat mengakibatkan volatilisasi amonia (Homidan et al., 2003). Kadar air litter yang optimal berkisar antara $20-25 \%$ apabila kadar air litter lebih tinggi dari kisaran normal berakibat menjadi media hidup mikroorganisme (Metasari et al., 2014). Ekskreta merupakan tempat yang ideal untuk tumbuh dan berkembangnya mikroba yang mengurai asam urat menjadi amonia dengan dukungan suhu dan kelembaban (kadar air) litter, maka bakteri pengurai asam urat berkembang biak dengan baik (Rothrock et al., 2008). Ekskreta unggas terdiri dari air $76 \%$, nitrogen $47,66 \%$, asam urat $108,9 \mathrm{mg} / \mathrm{g}$ ekskreta (Namroud et al., 2008). Kecernaan protein yang meningkat akan meningkatkan penyerapan protein, sehingga $\mathrm{N}$ ekskreta yang dikeluarkan lebih rendah. $\mathrm{N}$ ekskreta yang rendah akan berdampak pada penurunan kadar amonia hasil dekomposisi dari $\mathrm{N}$ ekskreta. Kecernaan protein pakan yang meningkat akan mengurangi asam urat dan protein yang dikeluarkan bersama ekskreta, sehingga dekomposisi asam urat dan protein berkurang dan terbentuknya amonia juga berkurang (Chiang dan Hsieh, 1995). 
Tujuan penelitian ini untuk mengkaji kualitas dan kadar amonia litter pada ayam broiler yang diberi sinbiotik inulin ekstrak umbi gembili dengan bakteri Lactobacillus plantarum. Hipotesis penelitian yaitu penambahan sinbiotik inulin umbi gembili dengan bakteri Lactobacillus plantarum dapat memperbaiki pemanfaatan kecernaan protein, kualitas dan kadar amonia litter.

\section{METODE}

Penelitian dilaksanakan di kandang terbuka di Fakultas Peternakan dan Pertanian Universitas Diponegoro, Semarang. Materi yang digunakan dalam penelitian ini adalah ayam broiler day old chick (DOC) unsexed dengan rata-rata bobot awal $45.68 \pm 1,52 \mathrm{~g}$ dan sinbiotik dari inulin ekstrak umbi gembili dengan bakteri Lactobacillus plantarum .

Rancangan yang digunakan yaitu rancangan acak lengkap (RAL) yang terdiri dari 4 perlakuan dan 6 ulangan. Perlakuan yang diberikan adalah penambahan sinbiotik sebagai berikut:

T0 : ransum basal (tanpa penambahan sinbiotik)

$\mathrm{T} 1$ : ransum basal + Sinbiotik $1 \mathrm{ml} / 100 \mathrm{~g}$ ransum

$\mathrm{T} 2$ : ransum basal + Sinbiotik $2 \mathrm{ml} / 100 \mathrm{~g}$ ransum

T3 : ransum basal + Sinbiotik $3 \mathrm{ml} / 100 \mathrm{~g}$ ransum

Parameter yang diamati adalah kualitas litter (Kadar air, $\mathrm{pH}$, suhu, dan amonia). Ransum basal yang akan digunakan dalam pemeliharaan mengandung protein kasar (PK) $22,08 \%$ dan Energi Metabolis (EM) 3000 $\mathrm{kkal} / \mathrm{kg}$. Ransum basal dan kandungan nutrisi dapat dilihat pada Tabel 1.

Tahap pengambilan data dilakukan pada umur pemeliharaan 4 minggu. Data yang diambil adalah kualitas dan kadar amonia litter. Pengukuran kualitas litter meliputi kadar air, $\mathrm{pH}$, suhu, dan kadar amonia litter.

\section{Pengukuran Kadar Air Litter}

Metode pengukuran kadar air litter dilakukan berdasarkan metode AOAC (1988) yaitu dengan mengambil sampel litter sebanyak $1 \mathrm{~g}$ yang diambil setiap minggu. Sampel dioven menggunakan oven menjadi bahan kering. Kadar air litter dihitung dengan rumus sebagai berikut:

$$
\mathrm{KA}=\frac{(\mathrm{B}-\mathrm{A})-(\mathrm{C}-\mathrm{A})}{(\mathrm{B}-\mathrm{A})} \times 100 \%
$$

Keterangan:

$$
\begin{aligned}
& \text { KA : } \text { Kadar Air }(\%) \\
& \mathrm{A}: \text { Berat cawan }(\mathrm{g}) \\
& \mathrm{B}: \text { Berat cawan }+ \text { sampel sebelum } \\
& \text { oven }(\mathrm{g}) \\
& \mathrm{C}: \text { Berat cawan }+ \text { sampel setelah } \\
& \text { oven }(\mathrm{g})
\end{aligned}
$$

\section{Pengukuran pH Litter}

Metode pengukuran $\mathrm{pH}$ litter dilakukan sesuai dengan metode Garcia et al. (2018) yang dimodifikasi. Pengukuran sampel $\mathrm{pH}$ litter dengan mengambil $5 \mathrm{~g}$ sampel litter dan dihomogenisasi dengan $100 \mathrm{ml}$ aquades kemudian diukur menggunakan alat $\mathrm{pH}$-meter (Hanna, HI-2210, Hanna Inst., São Paulo, Brasil).

\section{Pengukuran Suhu Litter}

Metode pengukuran suhu litter dilakukan setiap minggu pemeliharaan dengan menggunakan thermometer digital dengan cara meletakkan sensor thermometer digital ke dalam litter. Setelah itu mengamati suhu pada alat thermometer digital tersebut menunjukkan angka suhu yang tertera dan mencatat hasilnya. Selama pengukuran suhu berlangsung, litter yang digunakan tidak di bolak-balik. Pengukuran berdasarkan metode Widodo et al. (2009) yang dimodifikasi.

\section{Pengukuran Kadar Amonia (N ekskreta)}

Metode yang dilakukan pada pengukuran kadar amonia dilakukan dengan cara modifikasi dari penelitian Sarjana et al. (2017) dengan menggunakan modified chamber yaitu dengan pengambilan litter 
Tabel 1. Komposisi dan kandungan nutrisi ransum basal penelitian

\begin{tabular}{lc}
\hline Bahan pakan / nutrient & Persentase (\%) \\
\hline Jagung Kuning & 48,00 \\
Bekatul & 12,90 \\
Bungkil kedelai & 28,00 \\
MBM & 10,80 \\
Mineral mix & 0,30 \\
Jumlah & 100,00 \\
\hline Kandungan nutrisi (\%) & \\
\hline EM (kkal/kg) & $3.038,33$ \\
Protein Kasar & 22,08 \\
Lemak Kasar & 3,53 \\
Serat Kasar & 5,19 \\
Calsium & 1,00 \\
Fosfor & 0,68 \\
Arginin & 1,54 \\
Methionin & 0,37 \\
Lisin & 1,22 \\
\hline
\end{tabular}

Keterangan: Dihitung berdasarkan tabel bahan pakan menurut Leeson dan Summer (2005)

yang dimasukkan ke dalam modified chamber kemudian mengukur kadar amonia menggunakan alat amonia detector dengan ketelitian 1 ppm yang dilakukan dengan pengambilan sampel litter sebanyak $20 \mathrm{~g}$. Sampel dimasukkan ke dalam modified chamber yang dilengkapi dengan amonia detector, selanjutnya hasil dikonversi ke dalam satuan ppm per gram litter.

\section{Analisis Data}

Data hasil penelitian di analisis ragam dengan uji $\mathrm{F}$ pada taraf 5\%. Apabila terdapat pengaruh perlakuan yang nyata dilanjutkan dengan uji beda wilayah ganda Duncan.

\section{HASIL DAN PEMBAHASAN}

Berdasarkan hasil analisis ragam, perlakuan berupa penambahan sinbiotik pada level $2 \mathrm{ml} / 100 \mathrm{~g}$ signifikan $(\mathrm{P} \leq 0,05)$ menurunkan kadar amonia dan $\mathrm{pH}$ litter, tetapi signifikan $(\mathrm{P} \leq 0,05)$ meningkatkan kadar air litter, sedangkan terhadap suhu litter tidak berpengaruh signifikan $(\mathrm{P}>0,05)$. Data selengkapnya disajikan pada Tabel 2.

Pengaruh Penambahan Sinbiotik terhadap Kadar Air Litter

Kondisi litter sebagai alas kandang dapat ditentukan dengan persentase kadar air dalam bahan litter. Penambahan sinbiotik pada level $2 \mathrm{ml} / 100 \mathrm{~g}$ signifikan meningkatkan kadar air litter $(\mathrm{P} \leq 0,05)$ dan mengarah pada optimasi pemanfaatan protein pakan. Berdasarkan hasil penelitian kadar air litter sebesar 16,32 - 19,14\%, nilai tersebut masih pada titik optimal kualitas litter dari penelitian Metasari et al. (2014) kisaran kadar air litter antara lain 20 - 25\%. Pada penelitian ini kadar air pada litter terjadi pada titik optimal kualitas litter yang artinya pada kondisi litter yang baik. Berdasarkan hal tersebut maka peningkatan kadar air litter yang terjadi akibat penambahan sinbiotik hingga level $3 \mathrm{ml} / 100$ g pakan diduga terjadi karena secara prinsip reaksi kimia pembentukan amonia didasari dengan asam urat yang memerlukan 4 molekul air $\left(\mathrm{H}_{2} \mathrm{O}\right)$ dan 1,5 molekul oksigen $\left(\mathrm{O}_{2}\right)$ 
Tabel 2. Rata-rata Kadar air, pH, Suhu dan Amonia Litter (Fase Finisher)

\begin{tabular}{lcccccc}
\hline \multirow{2}{*}{ Parameter } & \multicolumn{7}{c}{ Perlakuan } \\
\cline { 2 - 7 } & T0 & T1 & T2 & T3 & P & SE \\
\hline Kadar Air Litter $(\%)$ & $17,12^{\mathrm{b}}$ & $16,32^{\mathrm{b}}$ & $19,14^{\mathrm{a}}$ & $18,34^{\mathrm{a}}$ & 0,00 & 0,281 \\
pH Litter & $8,40^{\mathrm{a}}$ & $7,88^{\mathrm{ab}}$ & $7,35^{\mathrm{b}}$ & $7,40^{\mathrm{b}}$ & 0,02 & 0,239 \\
Suhu Litter $\left({ }^{\circ} \mathrm{C}\right)$ & 30,23 & 30,70 & 29,83 & 29,66 & 0,39 & 0,446 \\
Kadar Amonia Litter $(\mathrm{ppm})$ & $8,33^{\mathrm{b}}$ & $10,00^{\mathrm{a}}$ & $10,16^{\mathrm{a}}$ & $7,33^{\mathrm{b}}$ & 0,00 & 0,461 \\
\hline
\end{tabular}

Keterangan: Nilai rata-rata dengan superscript berbeda pada baris yang sama menunjukkan perbedaan yang nyata $(\mathrm{P} \leq 0,05)$

untuk dapat melepaskan amonia $\left(\mathrm{NH}_{3}\right)$ dan karbondioksida $\left(\mathrm{CO}_{2}\right)$. Menurut Patterson dan Adrizal (2005), proses pembentukan amonia diawali dengan uric acid yang dikatalisis oleh enzim urease dengan bantuan $4 \mathrm{H}_{2} \mathrm{O}+1 \frac{1}{2} \mathrm{O}_{2}$ menghasilkan $\mathrm{CO}_{2}$ menjadi $\mathrm{S}(+)$ - Alantoin. $S(+)$ - Alantoin dikatalisis oleh enzim $S(+)$ Alantoinase dengan bantuan $\mathrm{H} 2 \mathrm{O}$ menjadi alantoic acid. Alantoic acid dikatalisis oleh enzim Alantoate Amidohyrolase dengan bantuan $2 \mathrm{H}_{2} \mathrm{O}$ menjadi $\mathrm{S}(+)$ - Ureidoglycolate menghasilkan $\mathrm{CO}_{2}+2 \mathrm{NH}_{3}$.

$$
\underset{\text { (asam urat) }}{\mathrm{C}_{5} \mathrm{H}_{4} \mathrm{O}_{3} \mathrm{~N}_{4}}+\underset{\text { (bakteri ureolitik) }}{1 \frac{1}{2} \mathrm{O}_{2}}+\underset{4 \mathrm{H}_{2} \mathrm{O}}{4} \rightarrow \mathrm{NH}_{3}+5 \mathrm{CO}_{2}
$$

Gambar 1. Mekanisme pembentukan amonia (Patterson dan Adrizal, 2005).

Berdasarkan hal tersebut diatas peningkatan kadar air litter diduga terjadi karena tidak efisiennya reaksi volatilisasi amonia sehingga tidak membutuhkan air dalam jumlah banyak dan air tersebut diretensi di dalam litter sehingga berdampak pada peningkatan kadar air litter. Peningkatan kadar air pada litter disebabkan karena rendahnya tingkat pemanfaatan air dalam litter saat proses pembentukan amonia. Hal tersebut dibuktikan pada rendahnya kadar amonia yang terbentuk pada litter dan penurunan nilai pH pada litter.

\section{Pengaruh Penambahan Sinbiotik terhadap pH Litter}

Penambahan sinbiotik dari IEUG yang dikombinasikan dengan bakteri Lactobacillus plantarum signifikan menurunkan $\mathrm{pH}$ litter
$(\mathrm{P} \leq 0,05)$. Hasil penelitian menunjukkan bahwa pH litter berkisar antara 7,35 - 8,40. Menurut Homidan et al. (2003) derajat keasaman atau $\mathrm{pH}$ litter $<7$ dapat menurunkan volatilisasi amonia sebaliknya $\mathrm{pH}$ litter $>8$ dapat meningkatkan volatilisasi amonia. Pada penelitian ini nilai rata-rata $\mathrm{pH}$ pada litter setiap minggu selama pemeliharaan berada pada rentang 7 hingga mendekati 8 yang berarti amonia yang terlepas sedikit lebih tinggi. Berdasarkan hal tersebut penurunan $\mathrm{pH}$ litter pada penelitian ini diduga terjadi karena pemanfaatan protein yang lebih besar sehingga uric acid yang dikeluarkan lebih sedikit sehingga berdampak pada penurunan nilai $\mathrm{pH}$. Sebagai catatan pada penelitian yang sama dihasilkan nilai FCR lebih kecil pada T3 dibanding T0 (Unpublish data). Hal tersebut dapat didukung dengan data rata-rata bobot badan harian dari penelitian yang sama bahwa nilai rata-rata bobot badan harian signifikan meningkat (Unpublish data). Karakteristik uric acid sebagai basa lemah diduga dapat memberikan konstribusi terhadap $\mathrm{pH}$ litter, pada jumlah produksi uric acid ekskreta yang lebih rendah maka $\mathrm{pH}$ litter relatif menjadi lebih rendah. Menurunnya nilai $\mathrm{pH}$ pada litter maka ketersediaan uric acid sedikit. Berdasarkan hal tersebut maka penurunan $\mathrm{pH}$ litter akibat penambahan sinbiotik hingga level $3 \mathrm{ml} / 100 \mathrm{~g}$ pakan diduga terjadi karena uric acid yang dikeluarkan oleh ayam lebih sedikit sehingga berdampak pada penurunan nilai $\mathrm{pH}$ litter. Penurunan $\mathrm{pH}$ litter disebabkan karena sedikitnya degradasi mikroba asam urat dalam litter seperti Bacilus pasteurii yang 
merupakan bakteri ureolitik di litter yang dapat tumbuh optimal pada $\mathrm{pH} 8,5$. Menurut Ritz et al. (2004), salah satu bakteri ureolitik yang memfasilitasi pembentukan amonia adalah Bacillus pasteurii, dimana bakteri tersebut membutuhkan $\mathrm{pH}$ sekitar 8,5 untuk pertumbuhan yang optimal.

\section{Pengaruh Penambahan Sinbiotik terhadap Suhu Litter}

Suhu litter merupakan salah satu parameter yang penting untuk diperhatikan karena dapat menciptakan suasana nyaman bagi ayam. Penambahan sinbiotik kombinasi dari IEUG dengan bakteri Lacbacillus plantarum tidak memberikan pengaruh signifikan $(\mathrm{P}>0,05)$ terhadap suhu litter. Berdasarkan hasil penelitian suhu litter berkisar antara $29,66-30,70^{\circ} \mathrm{C}$. Knizatova et al. (2010) menyatakan bahwa suhu pada litter yang ideal berkisar antara $29-31^{\circ} \mathrm{C}$. Pada penelitian ini suhu litter masih berada pada rentang normal. Berdasarkan hal tersebut tidak adanya pengaruh terhadap suhu litter diduga karena kondisi litter yang baik tidak memacu aktivitas mikroorganisme untuk berfermentasi di dalam litter. Penulis menduga panas fermentasi yang dihasilkan oleh mikroorganisme itu tidak cukup efektif untuk mengakibatkan perbedaan suhu litter. Pada beberapa penelitian tingkat kepadatan kandang jauh lebih efektif meningkatkan suhu litter dibanding fermentasi.

Suhu pada litter dapat disebabkan karena fermentasi pada litter tetapi tidak sampai mempengaruhi perubahan suhu litter namun disebabkan oleh ayam yang berkontakan langsung dengan litter. Reiter dan Bessei (2000) menyatakan bahwa litter yang hangat sebagian karena ayam kontak langsung dengan litter. Berdasarkan hal tersebut diduga karena suhu litter dapat dipengaruhi oleh tingkat kepadatan kandang. Menurut Reiter dan Bessei (1999) membuktikan bahwa kepadatan kandang merupakan faktor yang mempengaruhi suhu liiter. Penelitian ini dilaksanakan dengan standar kepadatan kandang yang sangat rendah yaitu pada unit perlakuan $\mathrm{T} 0, \mathrm{~T} 1, \mathrm{~T} 2$ dan T3 masing-masing sebesar $6,8 \mathrm{~kg} / \mathrm{m}^{2} ; 7,4$ $\mathrm{kg} / \mathrm{m}^{2} ; 8,0 \mathrm{~kg} / \mathrm{m}^{2}$ dan $9,0 \mathrm{~kg} / \mathrm{m}^{2}$. Berdasarkan hal tersebut maka perubahan suhu litter akan lebih di dominasi oleh faktor kepadatan kandang sehingga menyebabkan terjadinya konduksi yang artinya panas tubuh ayam kontak langsung dengan litter. Pradeepta et al. (2015) menyatakan bahwa pelepasan panas tubuh ayam dapat dilakukkan dengan cara konduksi seperti menempelkan tubuhnya ke litter.

\section{Pengaruh Penambahan Sinbiotik terhadap Kadar Amonia Litter}

Penambahan sinbiotik kombinasi dari IEUG dan bakteri Lactobacillus plantarum mengalami penurunan terhadap kadar amonia litter $(\mathrm{P} \leq 0,05)$ yang berkisar antara 7,33 - 10,16 ppm. Menurut Ritz et al. (2004) menunjukkan bahwa kadar amonia maksimal 25 ppm. Berdasarkan hasil penelitian, kadar amonia berada pada level optimal emisi amonia maksimal sebesar $25 \mathrm{ppm}$. Penurunan kadar amonia dalam litter akibat penambahan sinbiotik pada level $3 \mathrm{ml} / 100 \mathrm{~g}$ diduga disebabkan oleh terjadinya peningkatan kecernaan protein dalam saluran pencernaan. Hal ini didukung dengan nilai kecernaan protein yang meningkat pada penelitian yang sama (Unpublish data). Peningkatan kecernaan protein dalam saluran pencernaan menyebabkan minimnya pembuangan protein yang tidak terserap sehingga ekskreta yang dihasilkan mengandung sedikit kadar amonia. Mahfudz (2006) menyatakan bahwa meningkatnya kecernaan protein dapat mempermudah metabolisme protein.

Optimasi pemanfaatan protein yang efisien akan menurunkan produksi uric acid sehingga aktivitas mikroorganisme pengurai uric acid menjadi amonia rendah. Nahm (2005) menyatakan bahwa asam urat membentuk $70 \%$ kandungan nitrogen dari ekskreta unggas yang bercampur dengan litter dan terdegradasi menjadi amonia. Penurunan kadar amonia diduga terjadi karena bakteri ureolitik yang mengurai asam urat dalam litter sedikit. Hal tersebut disebabkan karena $\mathrm{pH}$ litter yang mengalami penurunan dan 
$\mathrm{pH}$ tersebut berada dibawah 8,5. Menurut Ritz et al. (2004), pembentukan amonia disebabkan oleh bakteri ureolitik salah satunya adalah Bacillus pasteurii, bakteri tersebut membutuhkan $\mathrm{pH}$ sekitar 8,5 untuk pertumbuhan yang optimal. Kadar amonia yang rendah pada litter dipengaruhi oleh kelembaban, $\mathrm{pH}$ dan suhu pada litter. Kadar air pada litter yang meningkat namun masih berada pada titik optimal dapat menghambat dekomposisi amonia.

Kadar nitrogen relatif ekskreta terhadap konsumsi nitrogen memiliki nilai dibawah rata-rata dari hasil penelitian Bolu et al. (2011) menunjukkan bahwa keluaran nitrogen relatif ekskreta ayam broiler unsexed sebesar 1,76\%. Penambahan sinbiotik signifikan menurunkan kadar nitrogen relatif ekskreta. Penurunan kadar nitrogen relatif ekskreta disebabkan karena nitrogen merupakan komponen unsur protein, namun diduga terjadi keseimbangan asupan pakan dari jumlah protein kasar dan kualitas protein. Modulasi asupan pakan ayam broiler berasal dari jumlah protein kasar dan kualitas protein yang konsekuen.

\section{KESIMPULAN}

Berdasarkan hasil penelitian dapat disimpulkan bahwa penambahan sinbiotik dari kombinasi IEUG dengan bakteri Lactobacillus plantarum menurunkan $\mathrm{pH}$ litter berpotensi untuk meminimalisir pencemaran emisi amonia dalam kandang ayam.

\section{DAFTAR PUSTAKA}

AOAC. 1988. Official Methods of Analysis. 13th. Ed. Association of Official Analitical Chemist. Washinton, D. C.

Bolu, S. A., V. Ojo., G. A. Malomo., P. O. Oladele, dan T. O. Olonijolu. 2011. Dietary levels of protein and sustainable broiler production. J. Of Applied Agricultural Research. 3:139- 139 .

Chiang, S. H. and W. M. Hsieh. 1995. Effect of direct-fed microorganism on broiler growth performance and litter ammonia level. AJAS. 8 (2): 159 - 162.

Garcia, R. G., N. D. S. Lima., I. A.Naas., F. R. Caldara, dan S. Sgavioli. 2018. The typology of broiler house and the impact in the locomotion of broilers. Engenharia Agrícola, Jaboticabal. 38 (3): 326-333.

Homidan, A. Al., J. F. Robertson, dan A. M. Petchey. 2003. Review of the effect of ammonia and dust concentrations on broiler performance. World's Poultry Science Journal. 59 : 340 - 349.

Kim, J. W., J. H. Kim, dan D. Y. Kil. 2015. Dieatary organic acids for broiler chickens: a review. Rev. Colomb. Cienc Pecu. 28:109-123.

Knížatová, M., Š. Mihina., J. Brouček., I. Karandušovská, dan J. Mačuhová. 2010. The influence of litter age, litter temperature and ventilation rate on ammonia emissions from a broiler rearing facility. Czech J. Anim. Sci. 55 (8): $337-345$.

Leeson, S. and J. D. Summers. 2005. Commercial Poultry Nutrition. Third Edition, Nottingham University Press, Nottingham.

Mahfudz, L. D. 2006. Ampas tahu fermentasi sebagai pakan ayam pedaging. J. IlmuIlmu Pertanian Cakara. 21 (1): 39 - 43.

Metasari, T., D. Septinova, dan V. Wannlatle. 2014. Pengaruh berbagai jenis bahan litter terhadap kualitas litter broiler fase finisher di closed house. Jurnal Ilmiah Peternakan. 2 (3) : 23 - 29.

Namroud, N. F., M. Shivazad, and M. Zaghari. 2008. Effect of fortifying low crude protein diet with crystalline amino acid on performance, blood ammonia level and excreta characteristics of broiler chicks. Poult. Sci. 87(11):2250-2258.

Nahm, K. H. 2005. Evaluation of the nitrogen content in poultry manure. World's Poultry Science Journal. 59 (1) : 77 - 
88.

Patterson, P. H. and Adrizal. 2005. Management strategies to reduce air emissions; Emphasis - Dust and ammonia. Journal of Applied Poultry Research. 14 (3) : 638 - 650.

Pradeepta K. R., N. C. Behura., S. P. Sahoo., P. Panda., K. D. Mandal, and P. N. Panigrahi. 2015. Amelioration of heat stress for poultry welfare: a strategic approach. International Journal of Livestock Research. 5 (3): 1 - 9.

Reiter, K. dan W. Bessei. 1999. The behavior of broilers depending on group size and stocking density. Arch. Geflügelk. 64 (3): 93 - 98.

Reiter, K. dan W. Bessei. 2000. Influence of broiler stocking on the temperature in the bedding and animal area. Arch. Geflügelk. 64 (5): 204 - 206.

Rothrock Jr. M. J., K. L. Cook., J. G. Warren, and K. Sistani. 2008. The effect of alum addition on microbial communities in poultry litter. Poult. Sci. 87:1493-1503.

Ritz, C. W., B. D. Fairchild, and M. P.
Lacy. 2004. Implications of ammonia production and emissions from commercial poultry facilities: a review. J. Appl. Poult. Res. 13:684-692.

Sarjana, T. A., L. D. Mahfudz., M. Ramadhan., Sugiharto., F. Wahyono, dan S. Sumarsih. 2017. Emisi amonia dan kondisi litter pada kandang ayam broiler sistem terbuka yang mendapatkan additif berbeda dan kombinasinya dalam ransum. Prosiding Seminar Nasional Pengembangan Peternakan Berkelanjutan 15 November 2017. Sumedang, Indonesia.

Sjofjan, O. 2003. Kajian Probiotik (Aspergillus niger dan Bacillus spp) sebagai Imbuhan Ransum dan Implikasi Efeknya terhadap Mikroflora Usus serta Penampilan Produksi Ayam Petelur. Disertasi. Universitas Padjajaran, Bandung.

Widodo, N., Wihandoyo, dan Supadmo. 2009. Pengaruh level formalin dan frekuensi penambahan litter terhadap karakteristik litter ayam broiler. Buletin Peternakan. 33 (3) : 170-177. 